\title{
Multimedia-Based Interactive Learning Media Design for Piano Practice
}

\author{
Afrina Nurfizia Lestari*, Yudi Sukmayadi \\ Art Education Study Program, Postgraduate School \\ Universitas Pendidikan Indonesia \\ Bandung, Indonesia \\ *afrinan108@gmail.com
}

\begin{abstract}
This article discusses about the process of designing and the effectiveness of multimedia - based interactive learning media for piano practice in the form of interactive videos. The main topic discussed was about triads and seventh chords in the book Jazz Hanon by Leo Alfasy. Those practice materials are beneficial for basic jazz piano lessons as they belong to the most basic elements of jazz harmony. The researcher also offers interactive learning for multimedia-based piano practice which can be a learning medium that provides an obvious description as well directly demonstrates the triad and seventh chords material contained in the book Jazz Hanon by Leo Alfasy. The tutorial in the interactive video is made more detailed by presenting slow tempo examples to make it easier to follow in the training process. The method which was applied in this research is Research and Development. The process of designing this learning media consists of: 1) assessment of the concept (concept); 2) arranging design (design); 3) collecting material (material collection); and 4) assembly (making process). Based on these data, the researcher hopes that the design of learning media in the form of multimedia-based interactive videos can be used as an easy alternative in the piano practice process for anyone who needs it, because regular piano practice is very important to improve the skill. In addition, this multimedia - based interactive video for piano practice can be an interesting, effective, and easily accessible learning medium through social media.
\end{abstract}

Keywords-learning media, interactive video, multimedia, piano practice

\section{INTRODUCTION}

Nowadays, music is considered as an art that is always developing. Music is a very unique phenomenon that can be produced by human voices (vocals) and some musical instruments such as guitar, piano, violin, percussion and so on. There are so many popular musical instruments. Studying music can also help the performance of human's right brain [1]. Therefore, many people are interested in learning it, one of which is piano. Many of the legends of the top musicians who use piano as their main musical instrument. However, nowadays we frequently find that piano is not only played in every musical performance at various concert events. This shows that piano is no longer a musical instrument that is only owned by the upper class.

The development of music that is very popular in Indonesia has made music instrument courses, especially piano, become one of society favorites. In addition, piano lessons are considered more interesting by the community because they can be directly applied in playing popular songs. Music learning can be obtained in formal institutions such as music schools and non-formal institutions such as music course institutions. Many of public schools also have the piano music extracurricular activities to teach students about music and piano playing techniques. Even today there are many piano course institutions around us. Nevertheless, the high cost of piano lessons makes some people reluctant to learn them, all the more if the course place is far from where we live, so that we have to add some costs for transportation.

In addition, one of the constraints or weaknesses of our education system is that the learning methods applicable in Indonesia are still conventional [2]. Likewise related to the learning media used, the music teachers at the course institution stated that they still used the conventional learning methods, namely the lecture method in various music course institutions, according to the results of interviews and observations during piano learning course and how to learn through music book only. The lack of interactive learning media about learning music is one of the reasons that music learning is still carried out in the conventional way. Hence, it is necessary how to develop learning media that is able to stimulate students' interest in learning music, especially learning piano.

As the time goes, computers have become an alternative that can be applied in learning methods. Computer-based media can combine various kinds of media either for learning purposes or not. This variety of media includes text, images, audio, video, animation and even simulations, or what is commonly called multimedia. Therefore, based on the description above, the researcher assesses that music learning can be developed in terms of the media used to convey the learning material, in this case the researcher will take basic jazz 
piano material, namely about triads and seventh chords contained in the book Jazz Hanon by Leo Alfasy.

As previously explained, this learning media design is in the form of interactive videos. The reason is because $75 \%$ of people are more likely to watch videos than read documents, emails or even articles. Likewise, in learning, using or adding videos can improve people's ability to remember concepts and details with an increasing effect over time [3].

In this case, the researcher also use social media to share piano learning materials. Therefore, social media itself can be more useful for its users. This multimedia-based learning media design can be beneficial for anyone who wants to learn piano. The researcher hope that this learning media can be more interesting, easy to follow and can be accessed through social media (see figure 1 and 2).

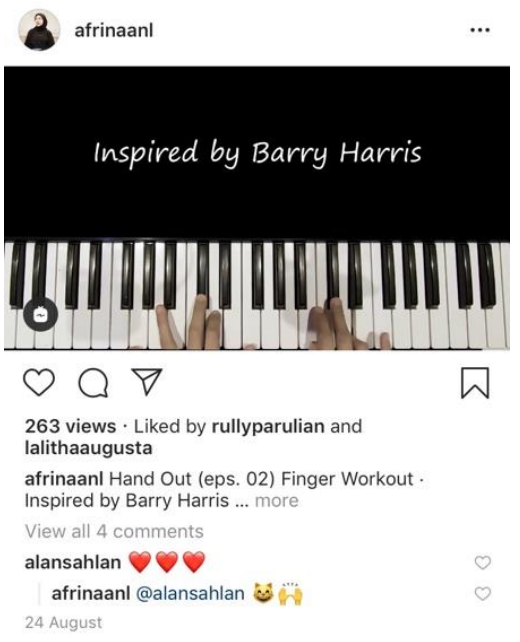

Fig. 1. Share piano learning on Instagram.

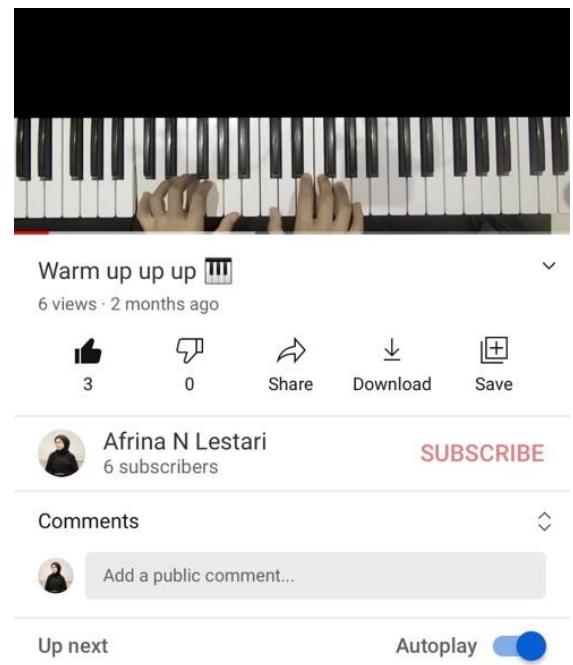

Fig. 2. Share piano learning on Youtube

\section{METHODS}

The research method used is the method of development research (Research and Development). Research and development that is carried out is oriented towards product development. Research and Development methods are research methods used to produce certain the products and test the effectiveness of these products [4]. In this learning media design, the development procedure used is the development procedure which was proposed by Luther where multimedia development is carried out in 6 stages including concept, design, material collecting, assembly, testing, and distribution [5]. However, if it is adjusted to the purpose of the researcher to design learning media, the media development stage does not reach the testing and distribution stage since this study only intends to design multimedia-based learning media in the form of interactive videos that can be accessed easily through social media.

In designing this multimedia-based learning media in the form of interactive videos, the researcher firstly conducted a research to collect the data by viewing and studying various references in the form of interactive videos in piano learning. Then, the researcher chose the material according to the researcher's plan. The Researcher also conducted several interviews with material experts in accordance with the learning theme to be given. In this stage, the researcher sufficiently obtained some description that the concept of interactive video itself depends on what material we are going to convey. Therefore, the various components in the interactive videos must be prepared in advance. After the concept of video and material was determined, the researcher carried out the process of making a video with various supporting properties such as camera, tripod, computer/ laptop, sound card, speaker, lighting and supporting software.

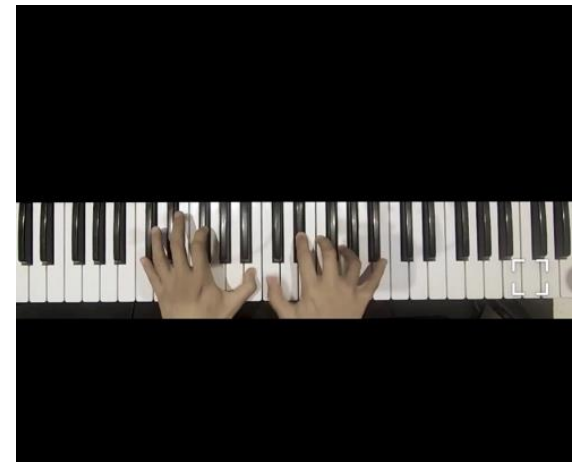

Fig. 3. Overhead camera placement.

During the video shooting process (see figure 3 ), the placement of the overhead camera was very effective so that the piano keys and hands could be seen obviously. Then in the process of shooting video to editing, the researcher was assisted by media experts so that the results are in accordance with the plan. From some of the research that has been conducted, the researcher develops several aspects so that the users can really understand the material presented through the 
media interactive video. The design used is minimalist but still attractive. The purpose is that the users stay focused on the material and can follow and understand it well. Sometimes when the interactive video design is abundant, the thing to worry about is that the users can be distracted. Hence, the language of conveying the material is one of the keys to the effectiveness of the interactive learning videos.

\section{DISCUSSION}

In this section, we will discuss some reviews about the design of multimedia-based learning media in the form of interactive videos for piano practice. Other than that, previously it has been explained that in learning and practice music, especially piano, the most of people still apply conventional learning methods [2]. Even though new methods that involve multimedia-based learning media will be interesting and beneficial for some people who need them. As there is no time to go to a piano lesson, there are budget consideration of the increasingly expensive piano lesson and various other reasons. Moreover, the reason why the researcher designed this learning media on social media is to be a reminder to do routine exercises for piano players, both those who want to learn or who are already learning. In this sophisticated era, most people are already owned social media. Therefore, social media itself will be more useful for its users. The following are some relevant reviews regarding the design of multimedia-based learning media for piano practice.

\section{A. Environmental Review}

The mushrooming of various piano educational institutions makes the society as audience and consumers confused about choosing their best piano education institution. The teaching system, curriculum, and fees are almost the same from one piano education institution to another, even some institutions offer a fairly high price. According to the results of field surveys and interviews, the number of piano educational institutions does not guarantee children's success in learning piano. There are several problems that students usually face in learning this musical instrument, including students not having enough time to practice piano because of the many student activities outside of school and internal factors, namely a lack of interest/enthusiasm for learning piano because it is difficult, the atmosphere of the practice room is uncomfortable/makes it difficult for students to concentrate. Meanwhile, to learn piano, it takes a high level of concentration. Apart from that in addition, some teachers sometimes cannot convey messages to children clearly about what they want to achieve while practicing, which makes children less understanding of the material, not motivated, and ultimately less interested in practicing piano. The teaching methods given by the piano teacher are not structural and make the students feel that learning piano is quite difficult. Therefore, it is necessary to have an interesting strategy in learning music, especially piano, so that the process runs according to the goal and triggers the importance of piano practice regularly.

\section{B. Interactive Learning Media}

What exactly is media? Media in general is an intermediary in learning. While media in Arabic means an intermediary or messenger from the sender to the recipient of the message. Meanwhile, according to the Kamus Besar Bahasa Indonesia (KBBI), interactive is the nature of taking action, between relationships, being mutually active. Based on the above statement, the interactive learning media is an intermediary used in the learning process where the sender and recipient of messages interact with each other. This was reinforced by Arrosyida who stated that interactive learning media was something related to software and hardware that could be used as an intermediary to convey the content of teaching the material from learning resources with learning methods that could respond back to users of what had been inputted into the media [6].

In the design of learning media for piano practice, the researcher made interactive videos where users can control the video themselves according to their wants and needs. The audio visual presentation and explanation in the video will help users to understand and follow the material. This video also provides detailed presentation of slower tempo performance to make it easier and provides a reminder that piano practice should be firstly started slowly. As we also know that such video formats can be downloaded and saved by the users as supporting documents for piano practice in order always to continue to increase motivation to practice regularly.

\section{Multimedia}

Before the $1980 \mathrm{~s}$ or in the $60 \mathrm{~s}$, multimedia was defined as a collection of various different media devices used for presentations [7]. In this case the interactive video designed by the researcher does present material for piano practice. Then after the 1980s, multimedia was defined as the delivery of information in an interactive and integrated manner which included text, images, sound, video or animation [8]. Hence, it can be concluded and also explained that multimedia can be used for the learning process of music, especially piano, so that it can stimulate thoughts, feelings, attention and interest to achieve learning goals. In general, learning multimedia has benefits to facilitate the effective learning process. The presentation of learning material for piano practice in the form of videos with audio visuals and attractive designs will help to stimulate the users to try and practice.

\section{Learning Multimedia Development}

In order to develop a good and effective interactive multimedia-based learning media, various ways are needed to produce good media. One of them is by implementing learning how to the media development procedures. The reason of that is development procedure is very important for evaluating what is less effective against the existing learning media. In the learning how to multimedia development procedure, there are six stages, namely concept, design, material collecting, assembly, testing, and also distribution [5]. As previously explained by the researcher at this paper, the media 
development stage that was carried out did not reach the testing and distribution stage because in this study it only intended to design multimedia-based learning media in the form of interactive videos that could be accessed easily through social media. If the design of multimedia-based music learning media in the form of interactive video can be completed according to the concept and purpose, then there is a possibility that the researcher will conduct a trial phase of the effectiveness of the media towards users and add other material.

\section{E. Piano Practice}

To master piano instruments, it takes regular practice. Exercise is the main key to improve abilities. However, what does a good and effective exercise look like? Musical practice as a multi-faceted activity. It suggested that an important dimension of learning to practice relates to how well a student is able to develop technical skills, musical interpretation, the ability to play from memory and to cope with performance stress [9]. These technical, cognitive, and performance skills cannot be only acquired by repetition. Therefore, it is important that teachers continue to provide practical advice on how to practice differently at different stages of learning.

Effective practice includes a number of learning strategies. One of the relevant strategies to this study, namely listening to the voice models such as teacher's demonstrations and recordings, is another practice strategy [10]. There is also a strategy that listening and seeing examples of practice models alone, without the opportunity to practice, it seems to be effective in helping to practice musicality [11]. Yet, still the musical instrument itself should be regularly practiced as much as possible. This conclusion is supported by research that has consistently detected better results in the accuracy of advanced instrumentalists which rely on modeling as a practical strategy. These studies provide credibility to Suzuki and other similar teaching methods, which are highly based on teacher imitation and recording [12]. Therefore, the researcher tries to make a multimedia-based music learning media design to help the piano practice process so that it can be a reference strategy in piano learning. It is also hoped that this will overcome the boredom of someone who is learning piano. Besides that, the freedom to control using this interactive video will help the users in the practice process.

\section{F. Jazz Piano Basic Practice Guide}

For anyone learning the piano musical instrument, of course, not only by playing it carelessly but also must be supported by a strong music theory. What is the reason? Well, music theory is a very important foundation and basis, especially to assist in accelerating the development of one's ability to master a musical instrument. Therefore, the design of multimedia-based learning media in the form of interactive videos not only shows or just demonstrates examples of material and finger games on the piano keys, but the theory and knowledge will also be explained briefly and clearly in the video.
The material chosen by the researcher in this design was an exercise on triads and seventh chords contained in the book Jazz Hanon by Leo Alfasy. In learning jazz piano, there are several things that must be mastered. However, in this important study, the researcher will immediately explain the importance of mastering triads and seventh chords in the basic jazz piano practice process. Actually, triad and seventh chords material is not only in jazz music. This is due to one of the most important essences that stands out in jazz music is the use of more complex chords or using extension chords. The basic chords in jazz generally use seventh chords and then develop according to the tension or development.

In the real of jazz, our words often come across the terms extension chord, tension, or more precisely the expansion and development of chords. Tension actually stands for extension. So, chord tension is an extension of the chord. It is this expansion that, if implemented properly, will make the color and taste of music even more "jazzy." Mark Fowler suggested that "The harmonic vocabulary of jazz consists of seven basic types of chords together with some "tension" notes and alterations. As in traditional harmony, jazz chords are built up in thirds from a root pitch; however, in jazz each basic chord consists of four different tones (bare major and minor chords are used sparingly in jazz, but they are common in current pop music)" [13].

In jazz harmony processing consists of seven basic types of chords along with several "tension" notes and changes. As in traditional harmony, jazz chords are constructed in three thirds of the root note. However, in jazz each basic chord consists of four notes. For instance, we have a $\mathrm{C}$ Major 7th (CM7) chord: $\mathrm{C}$ E G B. The tension or extension of the CM7 chord is from the notes D, F, A or notes 2,4 , and 6 . Because these notes will sound enhances the sense of "expansion" while for simultaneously elevating the tension of the chord (although it is not primarily a matter of tension). From this explanation, the researcher tried to make an interactive video design for piano practice with triads and seventh chords material taken from the book Jazz Hanon by Leo Alfasy. The book contains a variety of jazz piano practices which are quite effective so that triad and seventh chords material can be a first step to practice basic jazz piano.

\section{CONCLUSION}

Seeing the increasingly advanced developments and also technology that continues to develop from time to time, many people increasingly see that education outside of school such as music education is very important to help our brain development. Music education, especially piano instrument, is very popular music instrument with many people, however, it was found that some people find difficulty in sight reading skills to learn the piano, as the result it reduces the interest in learning music and they are "bored" with the piano because it is embedded in their mindset that learning piano is not easy. In fact, if piano is practiced regularly, it will improve our skills and good habits. These problems underlie the design of multimedia-based learning media in the form of interactive 
videos for piano practice. Therefore, the type of learning multimedia that will be used is media that refers to teacher instructions and tutorials for media which are fun and easy to access independent learning on social media.

Hopefully this interactive video will be a reminder to anyone who is going to learn piano or who has learned to always do piano practice regularly for good ability. In addition, the design of multimedia-based learning media can be a reference for other music teachers in teaching strategies. Furthermore, we as music teachers must also be able to create and develop music learning media and be able to operate various softwares that support the creation of attractive multimedia-based music learning media.

\section{REFERENCES}

[1] C. Wright, Listening to Music 6th ed. Chicago: Cengage Learning. 2010

[2] Kompas, Kurikulum Yang Mencerdaskan Visi 2030 dan Pendidikan Alternatif. Jakarta : PT. Kompas Media Nusantara. 2007.

[3] A. Pandey, 6 Strategi Pembelajaran Berbasis Video yang Wajib Digunakan di tahun 2019. Article. Elearning Industry. 2019.

[4] Sugiyono, Metode Penelitian Pendidikan Pendekatan Kuantitatif, kualitatif dan R\&D. Bandung: Alfabeta. 2009.

[5] A. H. Sutopo, Multimedia Interaktif dengan Flash. Edisi Pertama Ygyakarta: Graha Ilmu. 2003.
[6] A. Arrosyida, "Media Pembelajaran Interaktif Jaringan Komputer Menggunakan Macromedia Flash 8 di SMK Negeri 1 Saptosari”. Jurnal Pendidikan Teknik Informatika, (2), 1-8. 2015.

[7] S. Soenarto, "Pengembangan Multimedia Pembelajaran Interaktif Mata Kuliah Tata Hidang. Inotek: Jurnal inovasi dan aplikasi teknologi”, Volume 9, Number 1, February 2005.

[8] S. Harckbarth, The Educational Technology Handbook. New Jersey:Engle Wood Clifts. 1996.

[9] S. Hallam, What Do We Know about Practising? Towards a Model Synthesising the Research Literature. In H. Jorgensen \& A. C. Lehmann (Eds.), Does practice make perfect? Current theory and research on instrumental practice (pp. 179-231). Oslo, Norway: Norges Musikkhogskole. 1997.

[10] L.M. Gruson, Rehearsal skill and musical competence: Does practice make perfect? In J. A. Sloboda (Ed.), Generative processes in music (pp. 91-112). Oxford: Clarendon Press. 1988.

[11] R. Rosenthal, M. Wilson, M. Evans, and L. Greenwalt, "Effects of different practice conditions on advanced instrumentalists' performance accuracy”. Journal of Research in Music Education, 36 (4), 250-257. 1988.

[12] R. K. Rosenthal, "The relative effects of guided model, model only, guide only, and practice only treatments on the accuracy of advanced instrumentalists' practice". Journal of Research in Music Education, 32, 265-273. 1984

[13] M. Fowler, Jazz Chord. United States: Folk College. 2009. 